\title{
ASSESSMENT OF GENDER ACCESS TO AGRICULTURAL LOANS FROM COOPERATIVE SOCIETIES IN DEKINA LOCAL GOVERNMENT AREA OF KOGI STATE, NIGERIA
}

\author{
Adejo, P.E*., Adejo, E.G., Shaibu, U.M. \\ Department of Agricultural Economics and Extension, Kogi State University Anyigba, Nigeria \\ ${ }^{*}$ Corresponding author: E-mail: emmypar2002@yahoo.co.uk
}

Citation: Adejo, P.E., Adejo, E.G., Shaibu, U.M., 2017. Assessment of Gender Access to Agricultural Loans from Cooperative Societies in Dekina Local Government Area of Kogi State, Nigeria. J. Asian Rur. Stud. 1(2): 123-133

\begin{abstract}
This study assessed gender access to agricultural loans from cooperative societies in Dekina Local Government Area of Kogi State, Nigeria. Primary data used were collected from 160 registered cooperative members in the study area. Data collected were analysed using descriptive statistics, binary Logit regression analysis, and mean score. Results of the findings showed that $62.9 \%$ and $54.3 \%$ of the male and female cooperative members were married with household size of $1-5$ members. Most of the respondents were within the age bracket of $31-$ 50 years. Finding on gender difference indicated that male cooperative members had more access (3.52) to loan than the female (2.88). Estimates of the binary logit model showed that the slope coefficients of household size, educational status, years of membership, and income were positive and statistically significant at $10 \%$ and $5 \%$ for the male and female cooperative members respectively. Furthermore, the major problems faced by cooperative members in accessing loans are reluctance from financial institutions $(\mathrm{M}=2.8)$ and fear of repayment by borrowers $(M=2.7)$. Amongst others, comprehensive development of gender specific policy interventions by government to enhance access to loan by female cooperative members was recommended.
\end{abstract}

Keywords: Gender; Access; Cooperative; Credit; Women

\section{Introduction}

Gender roles are the socially ascribed roles of women and men, which vary among different societies and cultures, classes and ages, and during different periods in history. Gender-specific roles and responsibilities are often conditioned by household structure, access to resources, and specific impact of the global economy, and other locally relevant factors such as ecological conditions (FAO 2011 and Ekong, 2003). Interestingly, agricultural development has a lot to do with gender because all the cultural operations involved in agriculture are carried out by both the male and female farmers in all parts of the world, Nigeria inclusive. One of the major problems of agricultural development in Nigeria is that of developing appropriate organization and institution to mobilize and induce members of the rural sector to a greater productive effort (Odetola et al., 2015). As such rural farmers who are characterized by low 
income, low resource utilization, small farm holdings and scattered nature of farmland, finds it difficult to pool their resources together in order to raise their farm income and substantially improve their living conditions (Ibitoye, 2012). Over $80 \%$ of Nigeria's population lives in rural areas and majority is involved in agricultural activities. Contrariwise, there are no efforts to facilitate agricultural loan to both male and female farmers which is crucial in rapid the development of this dominant section of the population. This in essence, impedes agricultural productivity and growth (Odoemenem and Obinne, 2010). According to Federal Government of Nigeria (2008), 23\% of the adult population in Nigeria has access to formal financial institutions, $24 \%$ to informal financial services, while $53 \%$ are financially excluded.

Credit provision has been put forward as one of the principal components of rural development, which helps to attain rapid and sustainable growth of the agricultural sector. In rural setting, agricultural loan is a temporary substitute for personal savings, which catalyses the process of agricultural production and productivity. It is then suffice to say that, to boost agricultural production and productivity farmers have to use improved agricultural technologies, however the adoption of these technologies is relatively expensive and small holder farmers cannot afford to self finance it. As a result, the use of agricultural technologies is very low.

Loan is a necessary input in the various aspects of farm operations.

In Nigeria, as in most developing countries, lack of credit facilities has been regarded as the major constraint farmers' face when they try to improve their economic activities and/or living conditions (Agbor, 2004). Hence, most farmers form cooperatives in order overcome these constraints. Co-operatives are autonomous associations of persons who unite voluntarily to meet their common economic and social needs through a jointly owned and democratically controlled enterprise (Kumar et al., 2015). According to Yamusa and Adefila (2014), Co-operatives are established by like-minded persons to pursue mutually beneficial economic interest and they provide a unique tool for achieving one or more economic goals in an increasingly competitive global economy. Ojiagu and Onugu (2015) reported that Cooperatives have long been recognized to play important roles in society that translate into the improvement of living conditions of their members, particularly the low-income earning cadres of the population; the rural people and the urban poor. According to Kelegama and Tilakaratna (2014), South Asia has a long history of microfinance. Credit co-operatives have been in operation since the early 20th century in many South Asian countries. Lakshmi and Visalakshmi (2013) reported that cooperatives cover each \& every village of India. Cooperatives account for $46 \%$ of Agriculture Credit disbursement, Cooperatives aggregate people, resources and capital into economic units. Izekor and Olufohai (2010) explain that, it is the cooperative that embraces all type of farmers and a well organised and supportive Cooperative is a pillar of strength for agriculture in Nigeria. Ojiagu and Onugu (2015) added that being voluntary, democratic and self controlled business organizations, cooperatives offer the institutional framework through which local communities gain control over the productive activities from which they derive their livelihood. In South Asia, microfinance institutions (MFIs), including non-governmental organization (NGO)-MFIs, community-based organizations (CBOs), self-help groups, and cooperatives, play a dominant role in financial inclusion, in particular in terms of ensuring access to financial services for those from low-income groups and for women. About 
$80 \%$ of MFI borrowers in South Asia are women (Kelegama and Tilakaratna, 2014). Cooperatives provide the opportunity for farmers in the rural areas to raise their incomes. Creating a policy platform like the "financial inclusion" initiated by the Idian government will help cooperative members in Nigeria irrespective of gender or age the members. The financial inclusion was conceptualized as "The process of ensuring access to financial services and timely and adequate credit where needed by vulnerable groups such as weaker sections and low income groups at an affordable cost". This has had a positive impact on the cooperatives in India (Lakshmi and Visalakshmi, 2013). In China and Pakistan, the sucesses of some agricultural cooperatives had led to the metamorphosis of some cooperatives into Agricultural banks offering the rural cooperators more economically viable opportunities (Rheman et al., 2015). According to Kumar et al. (2015) there are a number of successful cooperatives in India itself like IFFCO (Indian Farmers Fertiliser Cooperative Ltd.) and KRIBHCO (Krishak Bharti Fertiliser Cooperative Ltd.) in the fertiliser sector, the Institution like AMUL in Dairy Sector and Self Help Groups (SHGs) formed by various Institutions have immensely benefitted farmer members in increasing crop productivity and overall income by generating support in various programmes related with agriculture.

Access to credit is the real problem among the countries in Central European and East African, as well as a whole range of other countries. According to Akram et al. (2012), the small farmers credit problems were more sever in Pakistan than Bangladesh and India. In Pakistan the credit cooperatives had been more interested to small farmer needs and offered no substitute but still their impact had been restricted because small farmers were unable to control them through participation at the decision-making level.

However, even when available, loan is difficult to access by farmers, especially female farmers in the rural areas despite the fact that it is an essential input in production (Foundation for World Agricultural and Rural Life, FARM, 2006). A study by World Bank (2001) concluded that women continue to be poorer due to lack of access to production resources such as loan; such disparities, hurt women's ability to participate in development activities and to contribute to higher living standards for their families. Hence, it becomes imperative to examine gender access to agricultural loans through cooperative societies. This is the thrust of the study. To achieve the broad objective, the following specific objectives were set out:

1. Describe the socioeconomic characteristics of cooperative members based on gender;

2. Ascertain the gender differences in accessing loan from cooperative societies;

3. Identify the problems faced by cooperative members in accessing loans; and

4. Identify the determinants of loan acquisition among cooperative members.

\section{Methodology}

\subsection{Study Area}

This study was carried out in Dekina local government area (LGA) of Kogi State, Nigeria. It is the largest Local Government Area in Nigeria in terms of the Land area, with a total of $7.691 \mathrm{~km} 2$. Dekina Local Government have a population of 260.312 people which represents $9.61 \%$ of the total population of Kogi State (NPC 2006). The local government is located on latitude $6.300 \mathrm{~N}$ and $7.300 \mathrm{~N}$ and longitude $7.000 \mathrm{E}$ and 8.000 E. About $80 \%$ of the people are farmers, engaged mostly in subsistence farming. 


\subsection{Sampling Techniques}

The population for this study involved all registered male and female cooperative members in the LGA. A simple random sampling technique was used to select the respondents for the study. The list of registered cooperative societies and its members were obtained from the local government headquarters (Social and Women Affairs Department). From the list, twenty (20) cooperative members (10 male and 10 female) were randomly selected from each of the eight registered cooperative societies. A total of 160 respondents were surveyed. However, seventy (70) questionnaire each, were properly filled and analysed. A total of 140 questionnaire were analysed using descriptive and inferential statistics.

\subsection{Method of Data Analysis}

Descriptive statistical tools such as frequency counts, mean and percentages were used to achieve objectives 1,2 and 3. Mean score used in achieving objective 3 were obtained from Likert-type scale. Likert scale was developed by Rensis Likert in the 1930s; the three point Likert type of scale was used to identify the major problems faced by cooperative members in accessing loan as specified below:

\section{Opinion}

Very Serious (VS)

Serious (S)

Not Serious (NS)

The mean response to each item was calculated using the following formula:

$$
\bar{X}=\frac{\sum F X}{N}
$$

Where: $\bar{X}=$ means response, $\sum=$ summation, $F=$ number of respondents choosing a particular scale point, $\mathrm{X}=$ numerical value of the scale point and $\mathrm{N}=$ total number of respondents to the item

The mean response to each item was interpreted using the concept of real limits of numbers. The numerical value of the scale points (Response modes) and their respective real limits are as follows:

Not Serious (NS) $\quad=1$ point with real limits of $0.5-1.49$

Serious $(\mathrm{S}) \quad=2$ points with real limits of $1.50-2.49$

Very Serious (VS) $=3$ points with real limits of $2.50-3.49$

Decision Rule: the mean of these weights is $2[(3+2+1) \div 3=2]$. A mean score of 2 or more implied that the problem is serious while a mean score of less than 2 implied that the item associated with that mean score is not a serious problem.

Logit Regression Model was used to achieve objective 4. The application of the logit model in explaining effect of the explanatory variables (household size, age, educational status, years of membership, income) on the dependent variable (access of male or female cooperator) has been shown to be more precise and appropriate in analyzing the relationships involving binary dependent variable and a set of independent variables (Gujarati, 2005; Idrisa et al., 2010). 
The model employed in the analysis is specified as follows:

$$
\operatorname{LnY}=\operatorname{Ln}\left(\mathrm{P}_{\mathrm{i}} / 1-\mathrm{P}_{\mathrm{i}}\right)=\beta_{0}+\beta_{1} \mathrm{X}_{1}+\beta_{2} \mathrm{X}_{2}+\ldots+\beta_{\mathrm{n}} \mathrm{X}_{\mathrm{n}}+\mathrm{u}_{\mathrm{i}-}
$$

Where $\mathrm{Y}=$ is a binary variable defined as 1 if a male or female cooperative members has access to cooperative loan and 0 if a respondent does not.

$\mathrm{Pi}=$ Probability to access cooperative loan

$\mathrm{Ln}=$ Natural logarithm function

$\beta_{0}=$ A constant

$\beta_{1}-\beta_{\mathrm{n}}=$ Logistic regression coefficients

$\mathrm{X}_{1}-\mathrm{X}_{\mathrm{n}}=$ explanatory variables defined below;

$\mathrm{X}_{1}=$ Household size (number)

$\mathrm{X}_{2}=$ Age (years)

$\mathrm{X}_{3}=$ Educational status (years)

$\mathrm{X}_{4}=$ Years of membership (years)

$\mathrm{X}_{5}=$ Income (Naira)

Equation 1 was estimated for both male and female cooperative members in the study area.

\section{Results and Discussion}

\subsection{Socioeconomic Characteristic of Male and Female Cooperative Members}

The result in Table 1 shows dominant married male and female cooperative members in the area. It also indicated that it is relatively easier to find women who are divorced or widowed than men in the study area. The household distribution indicated that greater proportions of the male $(55.7 \%)$ and female $(67.1 \%)$ cooperative members had household size of $1-5$ persons, while $31.4 \%$ of the male and $30 \%$ of the female members had household size of $6-10$ persons, implying that they had relatively large households. House hold size enhances the output of members by contributing to the availability of family labour which tends to reduce the production cost.

The age distribution of the respondents indicated that majority of the male and female cooperative members fell within the age group of 31-50 years implying that the members were still in their active and dynamic age and can perform manual work. Espig (1992) argued that productivity decreases with advancement in age but maintained that it is within the age range of 60 years and above. Understanding the age distribution is important because Gul Unal (2000) stated that old age might pose a problem in agriculture because most of the work is physically demanding. Supportively, Adegbite (2009); and Yamusa and Adefila (2014) reported that most of the cooperative farmers fall within the age bracket of 41-50 years which implies that they are still within the active working age to be productive enough to repay whatever credit that is granted to them.

Looking at years of cooperative membership, greater proportion of the female cooperative members had between 6 to 10 years of membership while the male respondents had between 1 - 5 years of membership. By and large, female respondents have been involved in cooperatives for a longer period compared to their male counterparts.

On education, $41.4 \%$ of the male cooperative members had at most primary school education while $58.6 \%$ of them had post primary school education. Contrariwise, $50 \%$ of the female respondents had at least primary school education while $50 \%$ had post 
primary school education. This shows that the male cooperative members were more educated than the female members.

Table 1. Distribution of Respondents According to Socioeconomic Characteristics

\begin{tabular}{|c|c|c|c|c|}
\hline \multirow[t]{2}{*}{ Socioeconomic Characteristics } & \multicolumn{2}{|c|}{ Male } & \multicolumn{2}{|c|}{ Female } \\
\hline & Freq. & $\%$ & Freq. & $\%$ \\
\hline \multicolumn{5}{|l|}{ Marital Status } \\
\hline Married & 44 & 62.9 & 38 & 54.3 \\
\hline Single & 08 & 11.4 & 14 & 20.0 \\
\hline Widow/Widower & 13 & 18.6 & 15 & 21.4 \\
\hline Separated & 05 & 7.1 & 0 & 0 \\
\hline Divorced & 0 & 0 & 03 & 4.3 \\
\hline Total & 70 & 100 & 70 & 100 \\
\hline \multicolumn{5}{|l|}{ Household Size } \\
\hline $1-5$ & 39 & 55.7 & 47 & 67.1 \\
\hline $6-10$ & 22 & 31.4 & 21 & 30.0 \\
\hline $11-15$ & 05 & 7.2 & 02 & 2.9 \\
\hline Above 15 & 04 & 5.7 & 0 & 0 \\
\hline Total & 70 & 100 & 70 & 100 \\
\hline \multicolumn{5}{|l|}{ Age (years) } \\
\hline Below 20 & 03 & 4.3 & 11 & 15.8 \\
\hline $21-30$ & 17 & 24.3 & 12 & 17.2 \\
\hline $31-40$ & 23 & 32.9 & 21 & 30.0 \\
\hline $41-50$ & 20 & 28.6 & 23 & 32.9 \\
\hline $51-60$ & 05 & 7.1 & 03 & 4.4 \\
\hline Above 60 & 02 & 2.8 & 0 & 0 \\
\hline Total & 70 & 100 & 70 & 100 \\
\hline \multicolumn{5}{|l|}{ Years of Cooperative Membership } \\
\hline \multicolumn{5}{|l|}{$1-5$} \\
\hline \multicolumn{5}{|l|}{$6-10$} \\
\hline $11-15$ & 34 & 48.6 & 18 & 25.7 \\
\hline Above 15 & 22 & 31.4 & 28 & 40.0 \\
\hline \multirow[t]{3}{*}{ Total } & 10 & 14.3 & 09 & 12.9 \\
\hline & 04 & 5.7 & 15 & 21.4 \\
\hline & 70 & 100 & 70 & 100 \\
\hline \multicolumn{5}{|l|}{ Educational Status } \\
\hline No formal & 19 & 27.1 & 22 & 31.4 \\
\hline Primary & 10 & 14.3 & 13 & 18.6 \\
\hline Secondary & 31 & 44.3 & 20 & 28.6 \\
\hline Tertiary & 10 & 14.3 & 15 & 21.4 \\
\hline Total & 70 & 100 & 70 & 100 \\
\hline
\end{tabular}

Source: Field Survey, 2016

\subsection{Gender Difference in Accessing Loan from Cooperative Societies}

The mean response of respondents in accessing loan from cooperative societies is presented in Table 2. The result revealed that the male cooperative members had relatively more access (mean access $=3.52$ ) to loan than the female members (mean access $=2.88$ ). This is in line with the apriori expectation. Although the use of farm inputs in farm production is not mutually exclusive but access to loan should be given serious attention because it is used to hire the services of other farm inputs, purchase other farm inputs and service debts incurred in the previous production periods, with its 
multiplier effect on increased farm income, increased production efficiency, increased productivity and better standard of living. This finding is in tandem with the report of FAO (2011) which posited that women are farmers, workers and entrepreneurs, but almost everywhere they face more severe constraints than men in accessing productive resources, markets and services.

Table 2. Gender Mean Access to Cooperative Loan

\begin{tabular}{lll}
\hline & Gender Mean Responses & \\
\hline Access to Loan & Male & Female \\
& 3.52 & 2.88 \\
\hline
\end{tabular}

Source: Field Survey, 2016.

\subsection{Problems Faced by Cooperative Members in Accessing Loans}

Access to cooperative loans by male and female members is saddled with various factors as presented in Table 3. The result identified reluctance from financial institutions $(\mathrm{M}=2.8)$ and fear of repayment by borrowers $(\mathrm{M}=2.7)$ as major hindrances to loan accessibility among cooperative members in the area. The result implies that operators of credit sources are afraid of default by beneficiaries, and this is a serious problem to loan accessibility among the cooperative members.

Table 3. Mean Response on Problems Faced by Cooperative Members in Accessing Loan

\begin{tabular}{ll}
\hline Problems & Mean Score \\
\hline Reluctance of formal institutions & 2.8 \\
Fear of default & 2.7 \\
Difficulty in getting a referee & 2.4 \\
Lack of collateral security & 2.2 \\
Unstable government policy & 2.0 \\
Inadequate capital accumulation & 2.1 \\
Bureaucracy & 1.9 \\
\hline Source: Field Survey, 2016 & Note: Mean Score of 2 and above $=$ serious problem
\end{tabular}

The result also indicates that difficulty in getting surety $(M=2.4)$ and lack of collateral security $(\mathrm{M}=2.1)$ are among significant problems to access loan by cooperative members in the study area. The result could be substantiated by the remoteness of the communities from the city centers. Hence, the required surety could not be easily located in rural settings. The result on collateral could be peculiar to female cooperative members due to the cultural restriction on assets in major parts of Nigeria.

Others significant constraints to loan access among cooperative members in the area include inadequate capital accumulation $(\mathrm{M}=2.1)$ and unstable government policy $(M=2.0)$. This finding underscores an earlier report in similar study by Ibitoye (2012), that the most serious problems indicated by cooperative members include inadequate capital accumulation (96\%), government interference (86\%) and unavailability of loan (74\%). Akram et al. (2012) who carried out a study on the borrowing behaviour of 
towards institutional credit in Punjab reported that among the households studied, 43.58 percent households faced collateral problem, 30.76 percent households faced the problem of transaction cost, 17.49 percent of the households said that the procedure was time consuming and 7.69 percent of the household faced the problem of lack of information about credit.

\subsection{Determinants of Loan Acquisition among Male and Female Cooperative Members}

The determinants of loan acquisition among male and female cooperative members are presented in Table 4. The table presents the maximum likelihood estimates of the Logit model for both male and female respondents. The log-likelihood ratio (LR) statistics for the two models exhibited appropriate signs and are significant; meaning that the explanatory variables included in the two models jointly explained the probability of loan access by both male and female cooperative members in the area.

For the male respondents, the empirical result revealed that the slope coefficients of the cooperative member's household size, educational status, years of membership, and income were positive and statistically significant at $10 \%$. Educational status and years of membership were significant at 5\%. This result implies that as the male respondent's household size, years spent schooling, years of membership and income increase; the chance to access loan from cooperative society also increases. Hence, these variables are positive determinants of access to loan by male cooperative members in the area.

Indicatively, result for the female cooperative members is similar to that of the male (except that the coefficients were significant at 5\%). All the explanatory variables have the same direction of effect on the probability of access to cooperative loan when compared to the male members' model. This result implies that female cooperative members' household size, educational status, years of membership and income are positive determinants of access to cooperative loan in the study area.

This finding agrees with Godquin (2004) who reported that the provision of nonfinancial service such as training, basic literacy and health services has a positive impact on loan obtained by farmers. Additionally, Imonikhe (2010) reported that education provided by cooperative societies to their members enhances their ability to make accurate and meaningful management decisions.

Table 4. Logit Model Estimates of Loan Acquisition by Male and Female Cooperative Members

\begin{tabular}{llccc}
\hline \multirow{2}{*}{ Variables } & \multicolumn{2}{c}{ Male } & \multicolumn{2}{c}{ Female } \\
\cline { 2 - 5 } & Marginal Effect & p-values & Marginal Effect & p-values \\
\hline Constant & 19.332 & 0.02133 & 12.322 & 0.0201 \\
Household size & 0.036 & 0.094 & 0.042 & 0.103 \\
Age & -0.916 & 1.932 & -0.044 & 0.223 \\
Educational status (years) & 0.406 & 0.0013 & 0.2822 & 0.000 \\
Years of membership & 0.073 & 0.055 & 0.772 & 0.046 \\
Income & 0.038 & 0.083 & 0.069 & 0.028 \\
Log-Likelihood = & -17.838673 & & -19.22873 & \\
Prob>chi2=0.0001 & & & &
\end{tabular}

Source: Computed from Field Survey, 2016 


\section{Conclusion}

It can be inferred from the findings that male cooperative members had more access to cooperative loans than their female counterpart. By and large, access to cooperative loans by members is determined by household size, educational status, years of membership and income. Hence, for improved access to cooperative loans, both male and female cooperative members should be exposed to longer period of formal education as this will enhance their access to cooperative loans. Importantly, there should be a comprehensive development of gender specific policy interventions by government and other relevant agencies to enhance access to loan by female cooperative members. Also, financial institutions such as formal banks should endeavour to locate some of the lending institutions or outfits nearer to the rural dwellers such as the informal money lenders. Additionally, emphasis should be placed on proper family planning programme in the rural area as this will help to reduce household size of rural populace which will probably contribute to increase in household saving and decline in demand for loan facilities.

Thus, this research draws the attention of policy makers toward ensuring that rural farmers (males and females alike) should have access to productive resources particularly, cooperative loans irrespective of their gender since agriculture in Nigeria and most parts of the developing nations of the world is characterised by gender division of labour. This research shall contribut to the wealth of literature on gender access to productive agricultural inputs particularly access to cooperative loans. Future researchers can use the results of this study to improve researches into the areas of agricultural cooperative loans for rural farmers and particularly, gender disparity in the distribution and access to credits.

\section{References}

Adegbite, D. A (2009). Repayment Performance of Beneficiaries of Ogun State Agricultural and Multipurpose Credit Agency (OSAMCA) in Ogun State, Nigeria (2004 - 2007). American - European Journal of Sustainable Agriculture 3(i): 117 125.

Agbor RA (2004). An Impact Assessment of Cameroon Gatsby Trust Micro-credit Scheme in the Mile Four District, Cameroon; Report of International Project Management for NGOs, Participants Learning, December, 2004, Sweden.

Akram, W., Munir, S., Hashmi, M.H. and Saleem, R. (2012). Borrowing Behaviour towards Institutional credit in Punjab- A case Study of Faisalabad District. International Journal of Academic Research in Economics and Management Sciences, 1(5): $37-47$

Ekong, E. E. (2003) An Introduction to Rural Sociology (2nd edition). Dove Educational Publishers, Uyo, Nigeria. 84 pp.

Espis, A. F. (1992) Economics of Yam Production in Haryan, Indian Journal of Agricultural Economics 92 (7) 28-34

FAO (2011). The state of food and agriculture, Food and Agriculture Organization of the United Nations Rome, pp $1-160$.

Federal Government of Nigeria (2008). Enhancing Financial Innovation and Access (EFInA EFInA (Enhancing Financial Innovations and Access) (2008). Access to 
financial services in Nigeria: Key findings. <http://www.efina.org.ng/ Key_Findings.pdf

Foundation for World Agricultural and Rural Life (FARM) Reviews (2006). "Working Group Micro-credit: Proposed Terms of Reference".

Godquin, M. (2004). Microfinance Repayment Performance In Bangladesh: How to Improve The Allocation of Loan by MFLs. World Development journal, 32(11): 1909-26

Gujarati, D.N. (2005). Basic Econometrics. Tat McGraw-Hill Publishing Company Ltd, USA.

Gul Unal F. (2008) Small is Beautiful: Evidence of an Inverse Relationship between Farmsize and Yield in Turkey Working Paper No. 551. The Levy Economics Institute.

Ibitoye SJ (2012). Survey of the Performance of Agricultural Cooperative Societies in Kogi State, Nigeria. Eur. Sci. J. 8(28):98-114.

Imonikhe, G. A. (2010). Impact of Katsina State Agricultural Project (KSACAP) on Income and Productivity. International Journal of Agricultural and Rural Development, 1(4):115-124

Izekor, O.B. and Alufohai, G.O. (2010). Assessment of Co-operative Societies Effectiveness in Agricultural Credit Delivery in Ikpoba Okha Local Government Area, Edo State, Nigeria. African Journal of General Agriculture, 6 (3): 139 - 143

Kelegama, S. and Tilakaratna, G. (2014). Financial Inclusion, Regulation and Education in Srilanka. ADBI working Paper Series. http://www.adbi.org/workinpaper/ 2014/11/18/6506.

Kumar, V., Wankhede, K.G. and Gena H.C. (2015). Role of Cooperatives in Improving Livelihoof of Farmers on Sustainable Basis. American Journal of Educaional Research, 3(10):1258 -1266

Lakshmi, P. and Visalakshmi, S. (2013). Impact of Cooperatives in Financial Inclusion and Comprehensive Development. Journal of Finance and Economics, 1(3): 49 - 53

National Population Commission (NPC). (2006): Nigeria Population Figures. Available http://www.population.gov.ng/index.php?option=com_content $\& v i e w=\operatorname{artide} \& i d=8$ $\underline{9}$

Odetola, S.K., Awoyemi, T.T. and Ajijola, S. (2015). Impact of Co-operative Society on Fish Farning Commercialization

Odoemenem IU and Obinne CPO (2010). Assessing the factors influencing the utilization of improved cereal crop production technologies by small scale farmers in Nigeria. Available: http://www.indjst.org/archive/vol.3.issue.2/ innocent-17.pdf.

Ojiagu, N.C. and Onugu, C.U. 92015). Effect of Membership of Co-operative Organisations and determinants of Farmer-members' Income in Rural Anambra State, Nigeria. International Journal of Scientific and Technology Research, 4(8): $28-35$

Rheman, A., Jingdong, L., Du, Y., and Khatoon, R. (2015). Banking Role and Loan Schemes for Agricultural Development in China and Pakistan. Global Journal of Human-social Science: Economics, 15(7): 57 - 67

World Bank (2001): Engendering Development Through Gender Equality in Rights, Resources and Voice. World Bank Policy Research Report 21776. Washington, DC and London, UK: World Bank and Oxford University Press; 2001. 
World Bank. (2004). Nigeria: Women in agriculture, In: Sharing ExperiencesExamples of Participating Approaches. The World Bank Group. The World Bank Participating Sourcebook, Washington, D.C. http:/www.worldbank.org/wbi/ publications.html

Yamusa, I. and Adefila, J.O. (2014). Farmers' Co-operatives and Agricultural Development in Kwali Area Council of Federal Capital Territory, Abuja, Nigeria. International Journal of Humanities and Social Science, 4(7): 161 - 169. 